DRAFT OCTOBER 2, 2006

\author{
GAP FILLING IN THE ZONE OF INSOLVENCY \\ FREDERICK TUNG
}

\begin{abstract}
Attacks on shareholder primacy have come from numerous quarters, arguing for expansion of the class of beneficiaries of directors' fiduciary duties. Regarding duties to creditors - the focus of this symposium - a long line of cases has recognized that once a firm is insolvent, creditors should be the primary beneficiaries of directors' fiduciary duties. Then in 1991, Chancellor Allen's famous discussion in Credit Lyonnais identified a special "vicinity of insolvency." In that special situation when a firm approaches insolvency, Chancellor Allen suggested, creditors should be included with shareholders in the "community of interests" to whom directors owe fiduciary duties. Of late, even economically oriented scholars-typically defenders of shareholder primacy - have jumped in to argue for a broader class of beneficiaries. These scholars argue that directors should seek to maximize value not just for shareholders, but for all financial claimants of the firm as a group, and even performance creditors - those owed some contractual performance by the firm.

In this Article, I suggest that at least for commercial creditors, fiduciary duties that include such creditors are unnecessary and may be counterproductive. Much of my discussion focuses on bank lending to large companies. Bank creditors' relative sophistication and the nature of their contractual relations with their borrower firms suggest that ex post judicial gap filling should be rare. Bank loans are typically renegotiated well before the borrower firm reaches insolvency, leaving no contract gaps for courts to fill. Other discussion applies to commercial creditors more generally. In particular, the standard justification for including creditors as beneficiaries of directors' fiduciary duties - the fear of excessive risk taking, or "overinvestment," by managers of distressed firms—-seems a rather weak rationale.
\end{abstract}




\section{GAP FILLING IN THE ZONE OF INSOLVENCY FREDERICK TUNG}

\section{TABLE OF CONTENTS}

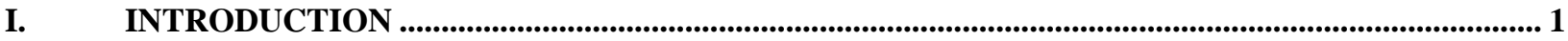

II. THE CASE FOR EXPANDING FIDUCIARY DUTIES ........................................................................ 4

A. FIDUCIARY DUTIES FOR INCOMPLETE CONTRACTING …................................................................. 5

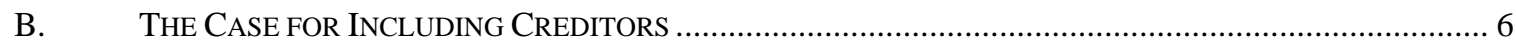

C. The CASE For Further EXPANSION OF FIDUCIARY DutIES ........................................................ 7

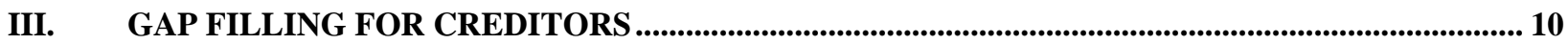

A. Do Sophisticated Lenders Leave Gaps in Their Contracts? ................................................ 10

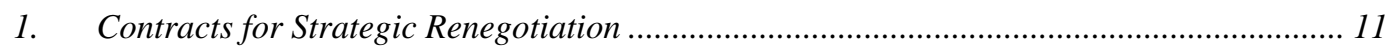

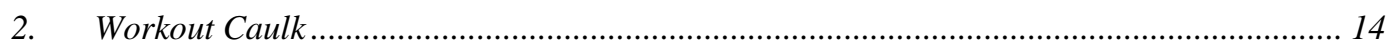

B. The OVERINVESTMENT Problem............................................................................................ 17

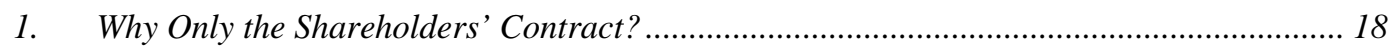

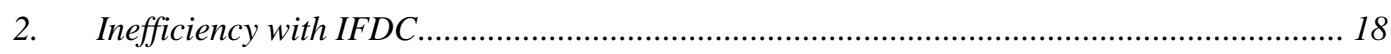

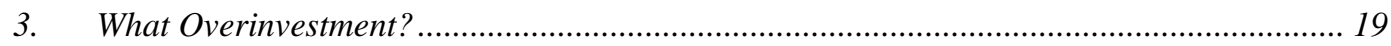

C. BEYOND OVERINVESTMENT: CAPM AND RATIONALLY DiVERSIFIED INVESTORS .......................... 20

1. Financial Value Maximization ........................................................................................... 20

2. Theoretical and Practical Considerations ..................................................................... 21

IV. ACTUAL BARGAINS IN THE VICINITY OF INSOLVENCY .......................................................... 23

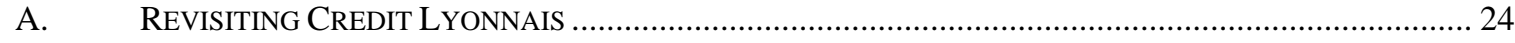

B. The Actual Bargain in Production Resources.................................................................... 26

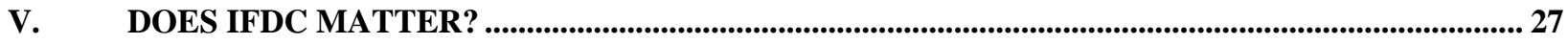

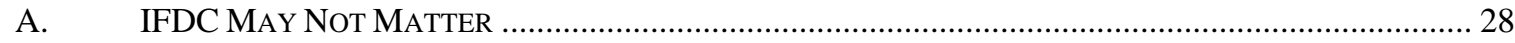


GAP FILLING IN THE ZONE OF INSOLVENCY

1. Procedural Context: the Business Judgment Rule, Limitations on Liability, and

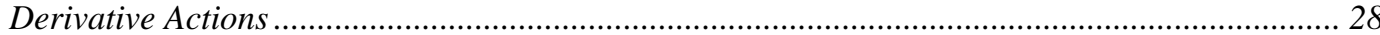

2. Existing Creditor Protection Rules ......................................................................... 29

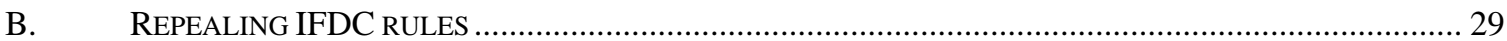

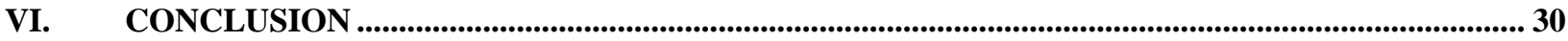




\title{
GAP FILLING IN THE ZONE OF INSOLVENCY
}

\author{
Frederick Tung*
}

Drafters should be reluctant to enact default standards without first asking why the standards were missing from private contracts. ${ }^{1}$

\section{INTRODUCTION}

Shareholder primacy is seemingly in tatters, and the question whether corporate directors owe a fiduciary duty to creditors as the firm approaches insolvency is merely a subset of the more general issue of shareholder primacy. Under the well-known shareholder primacy rubric_-long dominant among courts and commentators-directors' fiduciary duties run exclusively in favor of the corporation's common shareholders, and duty requires the board to maximize shareholder returns. The economic justification is straightforward: because common shareholders are the firm's residual claimants, they have the right incentives to maximize firm value. This is socially beneficial, as well as of private benefit to shareholders. Favoring shareholders with managerial fiduciary duties harnesses the zest for private wealth maximization to serve the broader goal of social wealth maximization. ${ }^{2}$

Attacks on shareholder primacy have come from numerous quarters, arguing for expansion of the class of beneficiaries of directors' fiduciary duties. Corporate social responsibility scholars have long championed a fiduciary duty broadened to include

\footnotetext{
* Professor of Law, Emory University School of Law. A.B. 1983, Cornell; J.D. 1987, Harvard Law School. Web: http://www.law.emory.edu/cms/site/index.php?id=ftung. E-mail: fred.tung@law.emory.edu. I owe special thanks to Bill Carney, Peter Huang, Jonathan Lipson, and Bob Rasmussen for comments on an earlier draft of this Article, as well as to participants in the symposium for which this Article was written-Twilight in the Zone of Insolvency: Fiduciary Duty and Creditors of Troubled Companies, held at the University of Maryland School of Law, November 4, 2005.

1 Alan Schwartz \& Robert E. Scott, Contract Theory and the Limits of Contract Law, 113 Yale L.J. 541, 602 (2003).

2 Frank H. EASTERBroOK \& DANiEL R. Fischel, The ECONOMiC Structure of CORPORATE LAW (1991).
} 
workers or local communities. ${ }^{3}$ Recent team production theory argues that directors are not and should not be directly accountable to shareholders or any other specific corporate stakeholder. Instead, in order to promote and protect firm-specific investment by diverse team members, directors owe fiduciary duties to "the corporate coalition as a whole." 4 Regarding duties to creditors - the focus of this symposium—a long line of cases has recognized that once a firm is insolvent, creditors should be the primary beneficiaries of directors' fiduciary duties. ${ }^{5}$ Then in 1991, Chancellor Allen's famous discussion in Credit Lyonnais identified a special "vicinity of insolvency." 6 In that special situation when a firm approaches insolvency, Chancellor Allen suggested, creditors should be included with shareholders in the "community of interests" to whom directors owe fiduciary duties. Of late, even economically oriented scholars - typically defenders of shareholder primacyhave jumped in to argue for a broader class of beneficiaries. These scholars argue that directors should seek to maximize value not just for shareholders, but for all financial claimants of the firm as a group, ${ }^{7}$ and even performance creditors-those owed some contractual performance by the firm. ${ }^{8}$

3 See Lawrence E. Mitchell, A Theoretical and Practical Framework for Enforcing Corporate Constituency Statutes, 70 TEX. L. ReV. 579 (1992); Kent Greenfield, Using Behavioral Economics to Show the Power and Efficiency of Corporate Law as Regulatory Tool, 35 U.C. DAVIS L. REV. 581 (2002).

${ }^{4}$ Margaret Blair \& Lynn Stout, A Team Production Theory of Corporate Law, 85 VA. L. REV. 247, 298 (1999).

5 See, e.g., Francis v. United Jersey Bank, 432 A.2d 814, 824 (N.J. 1981); Geyer v. Ingersoll, 621 A.2d 784, 787 (Del. Ch. 1992).

${ }^{6}$ Credit Lyonnais Bank Nederland, N.V. v. Pathe Communications Corp., Not Reported in A.2d, 17 DEL J. CoRP. L. 1099, 1155 \& n.55 (emphasis supplied).

7 See Thomas A. Smith, The Efficient Norm for Corporate Law: A Neotraditional Interpretation of Fiduciary Duty, 98 Mich. L. Rev. 214 (1999) (arguing that hypothetical contract among diversified investors would require directors to maximize sum of all financial claims against firm, and not just equity). For Smith, this broader fiduciary duty that would apply all the time-not just in financial distress. See infra Part II.C.

8 See Alon Chaver \& Jesse M. Fried, Managers' Fiduciary Duty Upon the Firm's Insolvency: Accounting for Performance Creditors, 55 VAND. L. REV. 1813 (2002) (arguing that in order to avoid inefficient managerial decisions, performance creditors must be included with financial creditors identified by Smith—so-called "payment creditors"). 
In this Article, I suggest that at least for commercial creditors, fiduciary duties that include such creditors are unnecessary and may be counterproductive. ${ }^{9}$ Throughout the paper, I use the term "IFDC" (insolvency fiduciary duties to creditors) to refer to the basic -and questionable-notion that for a firm at or near insolvency, creditors should be included in the class of beneficiaries to whom firm managers owe fiduciary duties. Much of my discussion focuses on bank lending to large companies. ${ }^{10}$ Bank creditors' relative sophistication and the nature of their contractual relations with their borrower firms suggest that judicial intervention to rewrite contracts ex post should be rare. ${ }^{11}$ Other discussion applies to commercial creditors more generally. In particular, the standard justification for IFDC - the fear of excessive risk taking, or "overinvestment," by managers of distressed firms_-seems a rather weak rationale.

${ }^{9}$ Fiduciary duties to other types of creditors may or may not be appropriate, an issue I do not engage here. Tort creditors may be the most sympathetic of claimants. Commentators have rightly noted the socially harmful cost externalization that corporations may visit on tort victims. As remedies, commentators have argued for unlimited shareholder liability; see Alan Schwartz, Products Liability, Corporate Structure, and Bankruptcy: Toxic Substances and the Remote Risk Relationship, 14 J. LEGAL STUD. 689, 716-17 (1985); Henry Hansmann \& Reinier Kraakman, Toward Unlimited Shareholder Liability for Corporate Torts, 100 YALE L.J. 1879 (1991); Nina A. Mendelson, A Control-Based Approach to Shareholder Liability for Corporate Torts, 102 CoLum L. REV. 1203 (2002); or priority for tort claims over contract claims; see Lynn M. LoPucki, The Unsecured Creditor's Bargain, 80 VA. L. REV. 1887 (1994), or both. See David W. Leebron, Limited Liability, Tort Victims, and Creditors, 91 ColuM. L. REV. 1565 (1991). See also Jonathan C. Lipson, Directors' Duties to Creditors: Power Imbalance and the Financially Distressed Corporation, 50 UCLA L. REV. 1189 (2003) (arguing that creditors with low volition, cognition, and exit opportunities should enjoy fiduciary duty of corporate managers).

${ }^{10}$ Consistent with a big company focus, I also take Delaware law as the primary exemplar of IFDC rules.

11 See Schwartz \& Scott, supra note 1. Creditors in the close corporation context may be less sophisticated. Corporate law has generally imputed greater fiduciary duties in the close corporation context than for public companies. See, e.g., Donahue v. Rodd Electrotype Co., 367 Mass. 578 (1975) (enunciating equal opportunity rule for close corporation stock repurchases). Consistent with this approach, unsophisticated creditors to close corporations may warrant stronger IFDC protections than sophisticated commercial creditors to public companies. See, e.g., Geyer v. Ingersoll Publications Co., 621 A.2d 784 
Part II recounts the trend to expand the universe of beneficiaries of corporate directors' fiduciary duties. It describes the standard contractarian framework for explaining shareholder primacy and the adaptation of this contractarian approach to include additional beneficiaries. In Parts III and IV, I question the contractarian case for fiduciary duties to creditors. Part III argues that sophisticated bank credit agreements may be substantially complete by the time a firm approaches insolvency. Through renegotiation - typical with defaulted bank loans - the parties have ordinarily had a second chance to fill any gaps in their contract by the time a firm approaches insolvency. ${ }^{12}$ The judicial gap filling championed by incomplete contracts theory may therefore be unnecessary. Part III also questions the overinvestment rationale for IFDC. Part IV relies on a few actual cases to illustrate the divergence between the hypothetical bargain of incomplete contracts theory and the actual bargains that creditors make with firms. Part V discusses the question whether IFDC rules are pernicious or merely harmless. Part VI concludes.

\section{THE CASE FOR EXPANDING FIDUCIARY DUTIES}

Ordinarily, shareholders are the only corporate stakeholders to whom firm managers owe fiduciary duties. Though other groups-creditors and employees, for example-are also interested in the corporation's success, their relations with the corporation are typically formed through and governed primarily by explicit contracts. ${ }^{13}$

(1992) (recognizing IFDC rights in dispute between two former partners of general partnership who later substituted corporate structure for partnership structure).

12 The prospect of renegotiation plays a prominent role in the initial structuring of relations between bank lenders and their borrowers. Because of information asymmetry and high enforcement costs, the parties are typically content to rely on ex post renegotiation to deal with borrower default, rather than attempt ex ante to contract for plausible contingencies. This indifference to conditioning performance on future states of the world contrasts sharply with the standard approach of incomplete contracts theory, which assumes that parties pursue cost-efficient ex ante contractual risk allocation. See infra Part III.A.1.

13 See William A. Klein, The Modern Business Organization: Bargaining under Constraints, 91 YALE L.J. 1521 (1982). My analysis of course excludes tort creditors and other involuntary claimants, whose predicament other commentators have addressed, through various proposals. See supra note 9 and accompanying text. 
These parties are generally expected to protect their interests through their explicit contracts. This Part recounts the trend toward expanded fiduciary duties for creditors.

\section{A. Fiduciary Duties for Incomplete Contracting}

According to the standard contractualist view of the corporation that has come to dominate corporate scholarship, corporate fiduciary duties should be viewed merely as gap filling devices for incomplete contracts between shareholders and firm managers. ${ }^{14}$ Because of shareholders' special status as residual risk bearers of the firm, their arrangement with the firm is necessarily open-ended. Shareholders ordinarily suffer the firm's marginal losses and enjoy its marginal gains. Every decision by the firm's management therefore directly affects shareholder wealth. Writing an explicit contract with firm management to govern this relationship would be uniquely difficult. It would be hopelessly incomplete, given the myriad complex decisions that firm managers must make in order to run the company. ${ }^{15}$ Instead, corporate fiduciary duty supplies a general gapfilling standard: firm managers should run the firm for shareholders' benefit. ${ }^{16}$ Fiduciary duty functions to complete the inevitably incomplete agency arrangement between shareholders and managers. In applying fiduciary duties, courts should attempt to fill in the hypothetical contract to which shareholders and managers would have agreed ex ante had they considered the issue later disputed. ${ }^{17}$

\footnotetext{
${ }^{14}$ EASTERBROOK \& FISCHEL, supra note 2, at 92.

15 Moreover, constricting managerial discretion too finely with detailed contracting frustrates managers' and investors' pursuit of the joint gains from specialization. Managerial decision making is what investors are buying when they invest their capital. They rely on managers' expertise in running the business, and constraints too stringent may hinder managers in pursuing the task. See id.

16 Shareholders also enjoy structural protections that encourage managers' attention to shareholder concerns. For example, shareholders elect and may remove directors. DeL. GEN. CORP. L. §§ 211(b), 141(k); MOdEL Bus. CORP. ACT. §§ 7.28(a), 8.08.

17 Trust, fairness, equity are all quaint concepts but beside the point. "Fiduciary duties are not special duties; they have no moral footing; they are the same sort of obligations, derived and enforced in the same way, as other contractual undertakings.” See Frank H. Easterbrook \& Daniel R. Fischel, Contract and Fiduciary Duty, 36 J. L. Econ. 425, 427 (1993) (footnote omitted).
} 
In general, when managers run the firm with the goal of maximizing shareholder returns, firm value is maximized as well, which benefits society. Shareholder primacy benefits not just private investors but society as a whole.

\section{B. $\quad$ The Case for Including Creditors}

When a firm is insolvent, creditors become the firm's primary residual risk bearers. ${ }^{18}$ Shareholders have essentially lost their bet on the company, and post-insolvency investments by the firm are gambles with the creditors' money. With creditors as the firm's residual claimants, the analysis goes, managers' fiduciary duties should shift to creditors. Instead of maximizing shareholder wealth, managers should instead look after the interests of creditors when the firm is insolvent. ${ }^{19}$ This approach is fairly settled law in Delaware and other jurisdictions.

With the firm's insolvency, managers would face perverse incentives under a shareholder primacy rule. ${ }^{20}$ Limited liability for shareholders means that shareholders enjoy the potentially unlimited upside from a spectacularly risky investment, but downside risk is borne by creditors. Firm managers faithfully pursuing shareholder wealth maximization, therefore, may be tempted to make very risky investments, since spectacular returns - however unlikely — would inure to the benefit of shareholders, while losses would be borne by creditors. Even investments with small or negative expected value for the firm

18 Margaret Blair and Lynn Stout, among others, have pointed out the numerous groups that have residual interests in the firm's financial success. See Margaret M. Blair \& Lynn A. Stout, Director Accountability and the Mediating Role of the Corporate Board, 79 WASH. U. L. Q. 403 (2001).

${ }^{19}$ Geyer v. Ingersoll, 621 A.2d 784, 787 (Del. Ch. 1992); Production Resources Group v. NCT Group, Inc., 863 A.2d 772, 790 (Del. Ch. 2004).

20 Jensen and Meckling showed us long ago, of course, that the agency cost of debt is more nuanced than the typical zone-of-insolvency discussion describes. Insolvency is not some magic event that triggers perverse incentives for managers that do not exist before insolvency. Instead, the agency cost of debt is increasing in the percentage of outside financing comprised of debt versus equity. See Michael C. Jensen \& William H. Meckling, Theory of the Firm: Managerial Behavior, Agency Costs and Ownership Structure, 3 J. Fin. ECON. 305, 344 (1976). 
would be pursued, as long as there were positive expected value to shareholders. ${ }^{21}$ Social welfare and shareholder welfare may diverge, then, when the firm is insolvent.

Delaware cases have also recognized that these perverse incentives for managers may operate even as the firm nears insolvency. The closer is the firm to insolvency, the greater the incentive for managers-now likely to be gambling at least in part with creditors' money - to make risky and even negative expected value investments in order to maximize shareholder returns. For Delaware courts, shareholders' special status begins to fade even before the firm becomes insolvent. ${ }^{22}$ In the amorphous "vicinity of insolvency," directors are instructed to include creditors with shareholders in the "community of interests” to whom directors owe fiduciary duties. ${ }^{23}$

\section{C. $\quad$ The Case for Further Expansion of Fiduciary Duties}

Now, one might view this insolvency or vicinity-of-insolvency problem as a peripheral concern. Most firms most of the time are not near insolvency, the thinking goes. So managers armed with the shareholder primacy dogma will have the right incentive to maximize firm value most of the time. So fiduciary duties to creditors may be merely a special situation requiring an unorthodox rule.

21 See Laura Lin, Shift of Fiduciary Duty Upon Corporate Insolvency: Proper Scope of Directors’ Duty to Creditors, 46 VAND. L. REV. 1485, 1489-91 (1993).

22 Courts and commentators seem to differ as to whether the proper beneficiaries of fiduciary duties in the "vicinity of insolvency" differ from those for a firm that is clearly insolvent. Compare Production Resources, 863 A.2d at 789-91 (holding that directors' vicinity-of-insolvency duty was to maximize firm value, but upon insolvency, duties run to creditors alone); Credit Lyonnais Bank Nederland, N.V. v. Pathe Communications Corp., Not Reported in A.2d, 17 DEL J. CORP. L. 1099, 1155 \& n.55 (suggesting that directors' duties in the vicinity of insolvency should run to the "corporate enterprise," which includes creditors as well as stockholders), with Royce de R. Barondes, Fiduciary Duties of Officers and Directors of Distressed Corporations, 7 GEO. MASON L. REV. 45, 71 (1998) (arguing that directors should promote creditor interests in the vicinity of insolvency, and that Credit Lyonnais creates an affirmative right of action for creditors). I ultimately suggest that any duty to creditors may be pernicious, so that I do not address these various distinctions.

${ }^{23}$ Credit Lyonnais, 17 DEL J. CoRP L. at 1155 n.55. 
The problem with this view, Tom Smith has argued,24 is that the "zone of insolvency" may not be a coherent construct. Big risky bets are increasingly available to firm managers. Bet-the-company projects are not hard to find. What this means is that managers do not have far to search for projects that will maximize shareholder value if successful but will leave the company insolvent if unsuccessful. In other words, the firm's "nearness" to insolvency - the value of its equity, in conventional balance sheet termsdoes not affect managers' latitude to make negative expected value bets that are good for shareholders. The only difference between a firm "near" insolvency in the conventional sense, and one that is not, is the size of the bet that would push the firm into insolvency. But shareholder primacy gives no guidance in this regard. It contains no limiting principle that tells managers above all not to bankrupt the firm. A diversified shareholder wants managers to take all shareholder wealth maximizing bets, especially those for which losses would be born by creditors! From this perspective, every firm is always in the zone of insolvency.

Smith further argues that shareholders are not the only stakeholders with imperfectly specified contractual rights against the corporation. Creditor contracts are similarly incomplete, albeit perhaps not in the same degree. For Smith, a hypothetical contract among fully diversified investors would not specify shareholder wealth maximization as its fundamental goal. The diversified investor-one who holds the market portfolio, according to Smith—would invest proportionally in the equity and bonds of every issuer. ${ }^{25}$ That investor would therefore be indifferent as to any distributional issues among the classes of an issuer's securities, as long as managers' actions maximized the sum of the values of the investor's financial claims on the company. The general charge for directors, then, should be financial value maximization (FVM): directors

\footnotetext{
24 See Smith, supra note 7.

25 Under CAPM, rational investors will diversify among all classes of capital assets, including both corporate stocks and bonds. In fact, they will hold the "market portfolio," that is, a portfolio that is a microcosm of all capital assets, in which each type of capital asset has the same place proportionally in the rational investor's portfolio as it does in the capital market as a whole.
}

Id. at 217. 
should seek to maximize the sum of all financial claims on the issuer, not just those of shareholders. ${ }^{26}$

Alon Chaver and Jesse Fried expand on Smith's analysis to argue for an even broader class of beneficiaries of directors' fiduciary duties. ${ }^{27}$ They question Smith's limitation that only financial claims deserve managerial fiduciary duties. Instead, Chaver \& Fried point out that performance creditors-parties owed contractual performance from the firm-need also to be part of the calculus, lest managers take inefficient actions in insolvency to benefit financial claims at the expense of performance creditors. With insolvency, firm managers can externalize some costs of contract breach since the firm will likely be financially unable to pay full expectancy damages to the other contracting party. Under Smith’s FVM approach, therefore, managers might be tempted to breach valuecreating contracts in order to benefit financial claimants, even when the cost of breach exceeds the benefit to financial claims. ${ }^{28}$ If performance creditors are cut out of firm managers' maximizing calculus, then the same problem that would plague society and bondholders in a world of shareholder value maximization would plague society and performance creditors in a world of financial value maximization. Managers might take actions that maximize financial claims but that harm performance creditors by an even greater margin. In other words, managers might make inefficient decisions. According to Chaver and Fried, shareholders would benefit ex ante from the "FVM-plus-performance creditors” approach, since performance creditors would offer better terms up front given this endgame protection. ${ }^{29}$

In the following two Parts, I suggest that these various approaches to crafting hypothetical contracts for creditors may be problematic.

\footnotetext{
${ }^{26} I d$.

27 See Chaver \& Fried, supra note 8.

28 See id. at 1834-35. Chaver and Fried also note the perverse incentive of firm managers to underinvest in the firm's capacity for contract performance when the firm is insolvent. See id. at 1831.
}

${ }^{29}$ Id. at 1843. 


\section{GAP FILLING FOR CREDITORS}

Theorizing about IFDC has to date suffered from abstraction. Scholars have proceeded with too-simple models of corporate contracting, which affects the framing of claimants' hypothetical bargains and conclusions about the content of these bargains. In this Part, I question the assumption that sophisticated credit contracts-bank lending agreements in particular-have gaps that judges can fill. I also suggest that problems of inefficient investment — to the extent they exist—may not be easily solved by expanding fiduciary duties.

\section{A. Do Sophisticated Lenders Leave Gaps in Their Contracts?}

Following the standard incomplete contracts approach, nexus-of-contracts corporate scholars explain fiduciary duties as contractual in nature. Fiduciary duty serves as the ultimate gap-filling device, completing the open-ended shareholder-manager contract with a hypothetical bargain crafted according to majoritarian default rules. Within the mainstream incomplete contracts literature, hypothetical bargain analysis is not without its skeptics. For example, much of the hypothetical bargain literature fails to defend or even discuss the presumed factor endowments of the parties to any hypothetical bargain. Party rationality and informational endowments in particular may be crucial factors for the substantive outcome of any majoritarian hypothetical bargain analysis. ${ }^{30}$

For our purposes, application of hypothetical bargain analysis to IFDC suffers from an important specific problem: by the time a firm is in the neighborhood of insolvency, it is far from clear that sophisticated credit contracts have gaps that need filling by courts. Often these contracts are renegotiated before the firm nears insolvency. For bank credit agreements especially, pre-insolvency workout is the norm. ${ }^{31}$ Bank and borrower have a

\footnotetext{
30 See David Charny, Hypothetical Bargains: The Normative Structure of Contract Interpretation, 89 MiCH. L. REV. 1815 (1991).

31 Gur Huberman \& Charles Kahn, Limited Contract Enforcement and Strategic Renegotiation, 78 Am. ECON. REV. 471 (1988); Charles Kahn \& Gur Huberman, Default, Foreclosure, and Strategic Renegotiation, 52 LAW \& ConTEMP. ProBS. 49, 51 (1989). Public debt contracts - bond offerings-are renegotiated via exchange offer, "the preferred technique of corporate management to effect a recapitalization and avert insolvency." John C. Coffee, Jr. \& William A. Klein, Bondholder Coercion: The Problem of
} 
second chance - and often multiple opportunities - to fill the gaps in their contract. Loan agreements may therefore be substantially complete by the time the borrower is in the zone of insolvency. Renegotiation has already filled any gaps that may have existed. In addition, because of this central role for renegotiation - which the parties anticipate at the time of their initial contract--the structure and function of bank loan agreements differ from the standard contract of incomplete contracts theory.

\section{Contracts for Strategic Renegotiation}

Incomplete contracts theory generally assumes that contracts aspire to full statecontingency. Bank loan agreements may not fit this premise. The theory assumes that parties try to "get it right" in the contract, specifying in a cost-efficient manner the agreed outcomes in the most plausible future states of the world. These aspiring-fully-statecontingent contracts condition the parties obligations, specifically allocating risk for the most likely scenarios. Contracting costs limit the extent to which the parties can cover all contingencies in their agreement, ${ }^{32}$ but the basic goal is to get it right-specifying the parties desired outcomes in the most likely future states-in order to avoid future disputes or costly renegotiation. ${ }^{33}$ Majoritarian defaults supplement the parties' efforts in this regard, economizing on contracting costs by supplying gap fillers to mimic the agreement the parties would have reached had they thought to address the particular contingency. ${ }^{34}$

Constrained Choice in Debt Tender Offers and Recapitalizations, 58 U. CHI. L. REV. 1207, 1224 (1991).

32 In a world of positive transaction costs, the parties will ideally negotiate and draft for progressively more remote contingencies until the marginal cost of contracting exactly equals the anticipated marginal benefit from addressing the particular contingency.

${ }^{33}$ See Ian Ayres \& Robert Gertner, Strategic Contractual Inefficiency and the Optimal Choice of Legal Rules, 101 YALE L.J. 729, 730 (1992) (describing standard view of incomplete contracts).

${ }^{34}$ More generally, majoritarian default rules reduce contracting costs by offering the parties an "off-the-rack" contract that most parties would prefer. Only a minority of contracting parties need expend costs to contract out of the law-supplied default. For refinements on this view of the desirability of majoritarian defaults, see Ian Ayres \& Robert Gertner, Filling Gaps in Incomplete Contracts: An Economic Theory of Default Rules, 99 YALE L.J. 87, 93-94 (1989) (identifying strategic incompleteness as alternative source of contract incompleteness, in addition to transaction cost explanation); Charny, 


\section{GAP FILLING IN THE ZONE OF INSOLVENCY}

Renegotiation is another possible approach to addressing unanticipated contingencies, but given the costs of renegotiation and strategic hurdles to its success, the original contract ought really attempt to "get it right" and thus avoid future disputes and the need for subsequent renegotiation. Gap filling aids the parties in getting it right.

The typical loan agreement, by contrast, seems to pursue a different goal. It makes no attempt to condition performance for all or even the most plausible future states of the world. Instead, the borrower's repayment obligation is absolute. ${ }^{35}$ On its face, the loan agreement seems harsh and inflexible. The borrower's repayment obligation obtains in all future states of the world. There are no excuses. No attempt is made to reduce the debt obligation or interest rate or adjust the payment schedule for the borrower's subsequent bad fortune or acts of God. ${ }^{36}$ Upon the borrower's default, the lender's remedies ordinarily enable it to severely damage or destroy the borrower's business. ${ }^{37}$

But the harshness of the agreement belies the reality of how things ordinarily go between bank and borrower. The lender typically forbears from exercising the severe remedies described in the original credit agreement. Instead, the parties renegotiate. From this vantage point, it appears every loan agreement is woefully incomplete. What the contract specifies is almost never what ultimately occurs; instead, renegotiation ensues. Clearly, what is going on here differs from the standard aspiring-fully-state-contingent contract of theory. Loan agreements are not trying to "get it right." Instead, the loan agreement can perhaps best be understood as a strategic device for structuring

supra note 30, at 1842 (noting that cost-minimizing default rule may not necessarily be majoritarian rule when costs of contracting out are asymmetric).

35 The loan contract is obligationally complete-that is, it fully specifies the borrower's obligation to repay the loan in full. See Ayres \& Gertner, supra note 33, at 730 (distinguishing between obligational incompleteness and contingent incompleteness). The loan agreement contains myriad other requirements as well, violations of which trigger default and immediate acceleration of the debt. See infra notes 47-48 and accompanying text.

${ }^{36}$ Moreover, multiple covenant obligations restrict the borrower's ability to engage in transactions or operate in a way that would impair its ability to repay. Covenant violations trigger default, even when the borrower has not missed a payment.

${ }^{37}$ See infra notes $49-50$ and accompanying text. 
renegotiation in the event of default. The agreement sets the parties' leverage-basically giving it all to the lender-in order to enhance the prospects for efficient renegotiation should it later be required. ${ }^{38}$

The lending relationship is characterized by information asymmetry and high contracting and enforcement costs. Contracting for renegotiation may be a useful device in this environment. ${ }^{39}$ The borrower will understand its operations and markets better than the lender. Many likely contingencies may be difficult to observe or impossible or prohibitively costly to verify - to prove in court. A borrower's default might be caused by any number of disparate factors, but only the borrower may know for sure. Even after default, the borrower's assets will ordinarily be worth more in the hands of company management than in the lender's hands. Whether the lender will be able to extract any of that value for repayment, however, may depend on the cause of default, which the lender must investigate. If default was caused by exogenous events-general economic conditions, for instance-the lender might as well leave the assets with the borrower and allow the business to continue. The borrower's management may be best situated to realize value from the firm's assets; the lender is unlikely to be better. ${ }^{40}$ On the other hand, if default was caused by circumstances peculiarly within the borrower's control—fraud or mismanagement, say-the lender will not generally wish to leave the assets with current management. The assets are worth more to the lender in its own hands. ${ }^{41}$

38 Kahn \& Huberman, supra note 31, at 61; Huberman \& Kahn, supra note 31, at 480; Marshall E. Tracht, Renegotiation and Secured Credit: Explaining the Equity of Redemption, 52 VAND. L. REV. 599, 624 (1999).

39 See Kahn \& Huberman, supra note 31, at 51.

40 Bringing in new management is also a possibility. See Douglas G. Baird \& Robert K. Rasmussen, Private Debt and the Missing Lever of Corporate Governance 154 U. PA. L. REV. (forthcoming 2006) (manuscript at 28). That has its own perils, however, and lenders are not likely to resort to this strategy precipitously.

${ }^{41}$ More generally, the lender may willingly share exogenous risk with the borrower, but not endogenous risk. The borrower is peculiarly situated to control for the risks of fraud or incompetent management. Understandably, the lender expects the borrower to bear the entire risk of those contingencies. When those contingencies come to pass, the lender pursues collection and asset realization aggressively, according to letter of the loan agreement. 


\section{GAP FILLING IN THE ZONE OF INSOLVENCY}

Contracting for these various contingencies would be tricky. Defining and distinguishing the various potential causes of default to the satisfaction of the parties would be a drafting nightmare. Even apart from contractual specification, some causes of default might be impossible to observe or verify. Even if the bankers are be able to tell whether default was caused by endogenous or exogenous events - they may be able to distinguish fraud or mismanagement from a general economic downturn-contracting against endogenous risk ex ante and proving endogenous causes of default to third parties ex post would be difficult in all but the most obvious cases.

Given these contracting and enforcement costs, it may make sense ex ante to anticipate renegotiation in the initial credit agreement and to place enormous leverage in the hands of the lender upon default. The possibility of draconian remedies upon default reduces adverse selection ex ante and may induce good behavior on the borrower's part ex post. ${ }^{42}$ Because the borrower has private information about the condition of the business, it is important that upon default, the lender have significant bargaining power in order to be able to extract as much value as possible in a workout. ${ }^{43}$ The lender's ability to shut down the business provides such leverage. This arrangement inures to borrowers' benefit as well. In the competitive lending markets in which banks operate, reducing banks' losses translates into lower borrowing costs for firms.

\section{Workout Caulk}

More than any other type of contract, a credit agreement crafted by a sophisticated lender anticipates the zone of insolvency. Indeed, a primary purpose of the agreement from the lender's standpoint is to rein in managerial discretion, and upon default, to give the lender leverage over the firm's management to impose even tighter controls. Sophisticated creditors typically get a second chance to fill their own gaps, to the extent

\footnotetext{
42 The lender does not have to prove fraud upon default in order to shut down the business. Even suspecting it is sufficient, since the lender's decision to pull the plug is not conditioned on the underlying reason for default.

43 See Kahn \& Huberman, supra note 31, at 51 (explaining that credit agreement puts enormous negotiating leverage in creditor's hands, not necessarily to enable creditor to foreclose but to extract value from borrower under conditions of information asymmetry).
} 
they exist, when the firm defaults. At that point, a "workout" - contract renegotiationensues. ${ }^{44}$ Financial covenants in the standard credit agreement are typically set to trigger a technical default well before the firm becomes insolvent. ${ }^{45}$ Workouts therefore generally occur before the firm approaches insolvency. Given this common practice of workout among corporate borrowers and their institutional lenders, judicial gap filling at or near insolvency may be unnecessary. Credit contracts may be complete in important respects by the time a firm approaches the zone of insolvency.

Creditors agree on a fixed return. Their upside is specifically capped at a given interest rate, so they have little stake in the upside of the firm's performance. They care primarily about damage control on the downside, and their credit contracts reflect this. ${ }^{46}$ The average maturity of a new bank loan to a public company is less than six and a half years. ${ }^{47}$ Use of loan proceeds is restricted. Regular operating reports to the bank are required. Negative covenants restrict the firm's ability to engage in many types of transactions without the bank's consent. The firm's latitude to incur new debt, make investments or distributions, engage in transactions with affiliates, sell substantial assets, give liens on its assets, merge, or change the nature of its business, are all explicitly restricted in the loan agreement. Myriad technical default provisions in the contract enable the bank to tighten the reins well before the firm flirts with the zone of insolvency. Financial covenants, for example, require the firm to maintain certain levels of net worth, tangible assets, total capital relative to debt, and cash flow relative to debt service obligations. 48

\footnotetext{
${ }^{44}$ Kahn \& Huberman, supra note 31; Huberman \& Kahn, supra note 31.

45 George G. Triantis \& Ronald J. Daniels, The Role of Debt in Interactive Corporate Governance, 83 CAL. L. REV. 1073, 1093 (1995).

46 See, e.g, Form 8-K filed by Staples Inc. (Dec. 20, 2004) (describing 2004 Revolving Credit Agreement with Bank of America); Form 8-K filed by Stride Rite Corp. (Sep. 22, 2005) (describing revolving credit agreement with Bank of America).

47 Scott L. Lummer \& John J. McConnell, Further Evidence on the Bank Lending Process and the Capital-Market Response to Bank Loan Agreements, 25 J. FIN. EcON. 99, 115 \& Table 5 (1989).

48 Bond indentures contain similar provisions. See, e.g., U.S. Bank National Ass'n v. U.S. Timberlands Klamath Falls, L.L.C., 864 A.2d 930 (Del. Ch. 2004). The court's detailed
} 
Once the debtor defaults, the bank enjoys enormous leverage to negotiate any additional protections it desires. A properly drafted credit agreement ordinarily offers default triggers and remedies that would allow the creditor to destroy the business. The lender's simplest leverage on default is its discretion to seize the borrower's cash and cut off its credit. ${ }^{49}$ This remedy brings the business to a halt. Formal acceleration of the debt is another severe option. Formal acceleration would typically trigger cross-default provisions in the firm's other debt contracts and other agreements. Other creditors would therefore also be able to pursue collection against the firm. Triggering a race among creditors to seize the firm's assets would damage the business severely, and might cause the firm's demise. If the lender were secured under the original loan, seizing its collateral would similarly hobble if not destroy the business. In exchange for forbearance, the lender generally gets what it wants in workout. ${ }^{50}$

In workout, the leash on firm managers gets even shorter than it was under the original loan contract. Restrictions on managerial discretion tighten. Monitoring becomes pervasive. In addition to stricter financial covenants and stricter limits on the firm's transactions, the lender typically demands more frequent operating reports. The lender also takes control of all the firm's cash. Standard provisions in a workout agreement include a "lock box" arrangement, in which all the firm's cash receipts are deposited into an account controlled by the lender. Disbursements from the account are made only at the lender's discretion. Disbursements are typically made only to fund existing operations, and firm managers may be required to make daily application for cash. In addition, any firm assets over which the lender did not already enjoy a security interest would typically be pledged to the lender. Serial renegotiation of the same loan is not unusual. Especially for seasonal businesses, circumstances may change from month to month or quarter to

technical discussion of note indenture provisions in that case illustrates the thoroughness and complexity of creditor protections in standard credit arrangements.

49 A bank lender often requires its borrowers to maintain their deposit accounts with the bank. This creates a setoff right for the bank should the borrower default. The bank may seize the amounts in the deposit accounts to offset against the outstanding loan.

50 See supra note 43 and accompanying text. 


\section{GAP FILLING IN THE ZONE OF INSOLVENCY}

quarter. Once the bank's bad-loan monitoring mechanisms are in place, renegotiation to adjust covenants or payment schedules is not unduly costly.

A sophisticated bank creditor, then, seems hardly to need the benefit of a courttriggered default rule that shifts fiduciary duties in its favor as the firm nears insolvency. The creditor fills its own gaps. ${ }^{51}$ Its original contractual arrangement with the firm anticipates renegotiation in the event of default. The contract is designed to trigger default well before the firm approaches insolvency and to enhance the prospects for efficient renegotiation.

\section{B. The Overinvestment Problem}

Even if sophisticated creditors were not adept at filling gaps in their contracts with the firm, IFDC suffers from other problems. Inefficient vicinity-of-insolvency investment incentives for firm managers are thought to justify a special IFDC regime. In the vicinity of insolvency, the story goes, managers intent on maximizing shareholder value may overinvest - take on excessively risky and even negative expected value projects that benefit shareholders at creditors' expense. ${ }^{52}$ The social objection is not that creditors lose value, but that these projects destroy firm value. Creditors lose more than shareholders gain. In effect, IFDC rules police the shareholder-manager contract to curb inefficient endgame behavior by managers. ${ }^{53}$

This rationale for IFDC suffers from at least three criticisms. First, the contract between shareholders and firm managers is hardly unique insofar as it may turn out to be inefficient ex post. It is unclear why only that contract deserves judicial policing for ex post efficiency. Second, an IFDC rule generates its own inefficiencies. And finally, it is far from clear that overinvestment is a real problem.

\footnotetext{
51 Whether this IFDC default is merely redundant or worse is discussed in Part V below. 52 See Credit Lyonnais Bank Nederland, N.V. v. Pathe Communications Corp., Not Reported in A.2d, 17 DEL J. CORP. L. 1099, 1155 \& n.55 (noting that managers should opt for course that maximizes expected value to firm as a whole, and not simply alternative that shareholders value most highly); Smith, supra note 7, at 221-22 (characterizing as "absurd result" a formulation of fiduciary duty causing managers to choose inefficient investment).
} 


\section{Why Only the Shareholders' Contract?}

One must ask why only the shareholders' contract deserves policing for endgame inefficiency. Contracts of all kinds may appear efficient ex ante but turn out to be inefficient ex post. No similar policing applies to credit contracts, for example. Just as managers may take excessive risk on behalf of shareholders through negative expected value projects, creditors may pull the plug inefficiently pursuant to the terms of their explicit contracts, forcing inefficient liquidation or precluding positive expected value investments in order to assure repayment of their loans. Investment restrictions are common in loan agreements, and again, especially in workout arrangements, management is kept on a fairly tight leash. The creditor's exercise of its contractual remedies may be inefficient ex post, but that turns out to be a risk in every contract. By itself, this circumstance seems insufficient to justify generalized judicial intervention.

Instead, we generally trust that private transacting will result in tolerably efficient outcomes overall. Renegotiation of contracts that turn out to be ex post inefficient is common, of course. But even if the parties fail to renegotiate to an efficient solution, this ordinarily does not justify court intervention.

\section{Inefficiency with IFDC}

Modifying managers' fiduciary duties to embrace creditors when the firm is at or near insolvency creates inefficiencies of its own. A project with positive expected value to the firm but negative expected value to creditors may be prohibited. IFDC addresses creditors' distributional concerns but may also result in inefficient investment policy to the extent an IFDC rule requires creditor primacy or incorporates some other form of creditor veto. ${ }^{54}$ Turning down projects that would maximize the value of the firm is socially undesirable, even if premised on avoiding disproportionate risk to creditors. 55

53 See Credit Lyonnais, 17 DEL J. CORP. L. at 1155 n.55.

54 Some have proposed, for example, a Pareto-improving rule to govern conflicts among claimants over the firm's investment decisions. See Morey W. McDaniel, Bondholders and Stockholders, 13 J. CoRP. L. 205, 246-47 (1988). See also David Millon, Redefining Corporate Law, 24 IND. L. REV. 223, 266 (1991) (proposing as first principle of directors' fiduciary duty to nonshareholder constituencies that management should forego short-term 
Moreover, compared to the overinvestment problem under a shareholder primacy rule, this IFDC inefficiency is likely to be much more difficult to negotiate around ex post. Placing an entitlement with creditors requires firm managers to negotiate affirmative permission from each creditor in order to pursue an efficient project. Holdout problems and other transactional impediments may preclude successful contracting. Managers may also be reluctant to seek such permission, as it might either signal the firm's shaky condition or prejudice managers in later litigation over the question whether the firm's financial condition had triggered an IFDC rule.

Ex-post IFDC inefficiency is difficult to renegotiate.56 Conversely, to curb overinvestment under shareholder primacy requires only one creditor-albeit a relatively sophisticated one-to negotiate ex post contractual limitations on management. This seems to occur frequently.

\section{What Overinvestment?}

Not only is a broad fiduciary duty to creditors too blunt to be efficient, but to date, courts' resort to IFDC rules has not been to police inefficient investment decisions-as the finance canon might suggest. Instead, the rule has been used more as a makeweight. Delaware courts have piled on the IFDC burden only after managers' conduct toward creditors is sufficiently unsavory that several other causes of action are also clearly available_-fraud or fraudulent transfer or veil piercing, for example. ${ }^{57}$

If overinvestment were a significant problem requiring IFDC, we would expect to see more invocation of IFDC in that context. But we don't. Moreover, empirical data

shareholder gains where transaction would frustrate legitimate nonshareholder expectations). Chancellor Allen's discussion Credit Lyonnais might also be read to incorporate such a limitation on investment decisions. See infra note 62.

55 FVM purports to remedy this inefficiency. But its underlying assumptions are quite strong, and its prescription suffers from verifiability problems. See infra Part III.C.

56 Cf. Ayres \& Gertner, supra note 34, at 119-25 (noting that varying levels of effort required to contract around default rules also determine when a "gap" exists for courts to fill).

57 See, e.g., Production Resources Group v. NCT Group, Inc., 863 A.2d 772 (Del. Ch. 2004). 
exists that casts doubt that overinvestment is a serious problem. ${ }^{58}$ It may be that creditors' contract protections provide a sufficient check on managers' overinvestment tendencies.59 It may be that managerial self-interest trumps any desire to bet the company in order to secure a return to shareholders. Managers interested in prolonging their tenure as managers would more likely pursue a conservative investment strategy, aiming for survival, rather than taking a spectacular do-or-die bet. Whatever the explanation, it is far from clear that endgame overinvestment by shareholder-wealth-maximizing managers is a serious problem. If it is not, then IFDC seems unnecessary at best.

\section{Beyond Overinvestment: CAPM and Rationally Diversified Investors}

As earlier mentioned, scholars have suggested even more drastic revisions to the standard shareholder-centered view of fiduciary duties. Financial value maximization (FVM) approaches have some plausible theoretical basis, but courts will have difficulty implementing such schemes.

\section{Financial Value Maximization}

Rather than simply effecting some shift in beneficiaries as the firm approaches insolvency, Tom Smith argues that directors' general charge should be to maximize the sum of the values of all financial claims on the firm. According to Smith, rationally diversified investors striking a hypothetical ex ante bargain over fiduciary duties would agree that corporate managers should pursue financial value maximization (FVM), not shareholder value. ${ }^{60}$ And this expanded duty should apply all the time. For Smith, the "zone of insolvency" is incoherent. All firms are always in the zone of insolvency because managers can always find a sizeable enough bet that puts all the firm’s equity at risk. ${ }^{61}$

\footnotetext{
58 See Barondes, supra note 22, at 59 (reviewing empirical literature).

59 By the time the borrower is flirting with insolvency, renegotiation has already curbed managerial discretion severely and put in place pervasive monitoring mechanisms. See supra Part III.A.2.

60 See supra note 26 and accompanying text.

61 See supra note 24 and accompanying text.
} 
This formulation is obviously inconsistent with shareholder primacy or creditor primacy. It may also preclude a "community of interests" approach. ${ }^{62}$ As long as expected financial value is positive, the firm should pursue the project, regardless of its distributional consequences among classes of financial claims, even if the project has a negative expected value for one class.

Alon Chaver and Jesse Fried generally accept of Smith’s FVM approach, adding one important amendment. They argue for inclusion of performance creditors in the netting algorithm once the firm's financial condition justifies inclusion of creditors under the protections of managerial fiduciary duties. Otherwise, the risk exists that firm managers might still make inefficient decisions in pursuit of FVM. ${ }^{63}$

\section{Theoretical and Practical Considerations}

An FVM approach relies on one very strong assumption about investor behavior. Not only are investors assumed to be rationally diversified-a common assumption in discussions of securities regulatory policy—but they are assumed to hold the market portfolio. Each investor holds capital assets of each firm in the proportions issued by the firm. In this context, it is easy to see how investors would be indifferent as to wealth transfers between classes of a firm's securities as long as total financial value were maximized. In fact, the assumption is so strong it eliminates the problem entirely. The assumption that all investors hold capital assets in the exact proportions issued by each

${ }^{62}$ Chancellor Allen's famous discussion in Credit Lyonnais is ambiguous on this question of efficiency versus distribution. He argues that directors' fiduciary duties should run to the "corporate enterprise," but his hypothetical does not address the thorny distribution problem. In his hypothetical, the advisable course maximizes firm value and also generates positive returns for creditors and shareholders. It leaves bondholders paid in full and offers some return to shareholders. Credit Lyonnais, 17 DEL J. CoRP. L. at 1155 n.55. It's not bad for anybody. So it fails to confront the difficult question whether the pursuit of firm value maximization may permissibly come at a risk to creditors. If including creditors in the "community of interests" implies some Pareto-improving criteria for any new project, then it is inconsistent with FVM, under which no class of financial claims enjoys any expectation of Pareto-improvement with respect to firm projects.

${ }^{63}$ See supra notes 27-29 and accompanying text. 
firm effectively assumes away all interclass investor conflict. It makes the hypothetical contract analysis pretty straightforward, but the assumption is doing all the work.

Of course, no investor actually holds the market portfolio. Even financial economists acknowledge its impracticality. ${ }^{64}$ As long as this is so, there will always be conflict among classes of financial claims. But perhaps the assumption, while quite strong, is still close enough? Many investors are diversified, and diversification to largely eliminate non-systematic risk may not require very many holdings. So while actual investors might not be indifferent as to distributional consequences in particular cases, they might still prefer FVM overall in order to maximize the value of their portfolios over the long run. ${ }^{65}$

Even if this is right—which is far from clear-FVM may be very difficult to implement. Courts will have difficulty comparing the effects of competing prospective investment alternatives on total financial value, or comparing the actual outcome of a chosen investment to the hypothetical outcome of an alternative investment that was never made. Creditors will have difficulty monitoring a firm's investment policy as well. ${ }^{66}$ This explains why bond indentures ordinarily rely on dividend and financing restrictions to

${ }^{64}$ Haim Levy, Equilibrium in an Imperfect Market: A Constraint on the Number of Securities in the Portfolio, 68 Am. ECON. REv. 643 (1978); Richard Roll, A Critique of the Asset Pricing Theory's Tests, 4 J. Fin. ECON. 129 (1977). Moreover, what counts as the appropriate "market" for purposes of the market portfolio is not without controversy. See id.

65 This scenario seems counterfactual, however, given the elaborate covenant protections that we observe in corporate bond indentures and loan agreements. Ninety-five percent of corporate bonds are held by large institutions. STAFF OF SENATE CoMm. ON GOVERNMENTAL AFFAIRS, $107^{\text {TH }}$ CONG., FINANCIAL OVERSIGHT OF ENRON: THE SEC AND PRIVATE-SeCtOR WATCHDOGS 78 (COMM. PRINT 2002). These are the investors we would most expect to be rationally diversified.

66 [P]roduction/investment policy is very expensive to monitor.... It is expensive even to ascertain when the firms' production/investment policy is not optimal, since such a determination depends on magnitudes which are difficult to observe. The high monitoring costs which would be associated with restrictive production/investment covenants... dictate that few production/investment decisions will be contractually proscribed. 
optimize the firm's investment policy, instead of covenants directly restricting investment policy. ${ }^{67}$ Any court-supplied standard for investment policy is difficult to police-even shareholder primacy_but adding new classes of beneficiaries is likely to complicate the task even further. ${ }^{68}$ The end result of such an approach may be to render managers accountable to no one. 69

More generally, FVM suffers from the same problem as other IFDC standards. Gap filling is a far weaker rationale for IFDC than for fiduciary duties to shareholders. In the situation where a sophisticated credit agreement leaves no gaps, it is hard to see how FVM should apply. Should FVM include creditors with their own contract protections? Or should the particular creditors with contract protection be deemed to have opted out of their default protection? Consistent with a gap filling theory, FVM would then charge managers to maximize value only for those financial claimants who had not opted out. The maximization calculus gets unwieldy pretty quickly. Ultimately, if commercial creditors generally protect themselves by contract, it is difficult to see why we need FVM or any other IFDC standard.

\section{ACTUAL BARGAins IN THE Vicinity OF INSOLVENCY}

Credit Lyonnais and the more recent Delaware decision in Production Resources ${ }^{70}$ form the endpoints of Delaware's vicinity-of-insolvency lineage. A quick look at these endpoints illustrates several things. First, it shows the extent of vicinity-of-insolvency renegotiation. Sophisticated creditors typically renegotiate, so that IFDC gap filling hardly

Clifford W. Smith \& Jerold B. Warner, On Financial Contracting: An Analysis of Bond Covenants, 7 J. FIN. ECON. 117, 153 (1979).

67 Id. at $125,153$.

68 As discussed below, given the business judgment rule and other liability-insulating features of corporate law, expanding the types of beneficiaries of managers' fiduciary duties may have little effect on managerial discretion. See infra Part V.A.1.

69 See William J. Carney, Does Defining Constituencies Matter, 59 U. CIN. L. REV. 385, 419 \& n.137-42 (1990) (using Arrow's theorem to illustrate accountability problem); Jonathan R. Macey, An Economic Analysis of the Various Rationales for Making Shareholders the Exclusive Beneficiaries of Corporate Fiduciary Duties, 21 Stetson L. Rev. 23 (1991) (arguing that other constituency statutes merely render managers accountable to no one).

70 Production Resources Group v. NCT Group, Inc., 863 A.2d 772 (Del. Ch. 2004). 


\section{GAP FILLING IN THE ZONE OF INSOLVENCY}

seems necessary. Second, even in addition to the parties' explicit gap filling by contract, other adequate legal remedies exist to constrain borrower misbehavior. IFDC offers at best redundant protection for creditors in the insolvency zone.

\section{A. Revisiting Credit Lyonnais}

From an incomplete contracts perspective, it is ironic that Credit Lyonnais should be the touchstone case for any vicinity-of-insolvency discussion. Though Chancellor Allen's important discussion of managers' perverse incentives is largely confined to a footnote-rightly in my view, given the facts of that case-and though Credit Lyonnais remains officially an unpublished opinion, it is widely regarded as the seminal judicial explication for expanding IFDC into the vicinity of insolvency. Later courts explicitly adopt the analysis in Chancellor Allen's dictum. Credit Lyonnais was not a case, however, crying out for judicial gap filling. Quite the opposite.

The case involved a workout between a sophisticated bank creditor on the one hand - Credit Lyonnais (the "Bank")—and a corporate borrower, MGM, and its controlling shareholder, Giancarlo Parretti, on the other. By the time the case descended into litigation, the parties had already implemented a complicated corporate governance arrangement. They had filled their own gaps. Credit Lyonnais was a major lender to both MGM and its parent. Its loans were secured by a controlling block of MGM stock. When MGM was forced into bankruptcy by its trade creditors, the Bank agreed to finance MGM's exit from bankruptcy, but with conditions. The Bank agreed to forbear from foreclosing on its stock pledge and taking explicit control of MGM, and the parties negotiated a Corporate Governance Agreement (CGA). This agreement set out a comprehensive scheme for management of MGM, including appointment of Alan Laddthe Bank's choice-for chairman and CEO and the formation of an executive committee to exercise almost all corporate powers delegable under Delaware law. ${ }^{71}$ At the insistence of

${ }^{71}$ Credit Lyonnais, 17 DeL J. CoRP. L. at 1118 . The power to file bankruptcy, issue securities or appoint or remove the chairman and CEO were all reserved to the board and would require a vote of four of the five directors. Id. After difficulties arose between the bank and Parretti over control of MGM under the CGA, a bank-nominated party acceptable 
the controlling shareholder Parretti, the CGA also included explicit "exit" strategies for MGM - conditions under which the CGA would terminate, thereby ending the Bank's influence over the firm's management. ${ }^{72}$ To insure compliance with the CGA, the Bank obtained the right to vote its controlling block of MGM stock pursuant to a voting trust. The Voting Trust Agreement creating this trust was placed in escrow, and the Bank was given sole discretion to break the escrow to render the voting trust effective. ${ }^{73}$ Parretti acceded to these arrangements.

Ultimately, Parretti breached the CGA by attempting to wrest control from the CGA-created management structure. The Bank terminated the escrow on the voting trust and exercised its voting power to remove Parretti and his confederates from the board of directors. The Bank followed with a suit for a judicial determination that its elected board was the rightful board of MGM.

In this suit, Parretti claimed that CEO Ladd breached his fiduciary duty to MGM's parent by failing to facilitate asset sales that Parretti sought in order to raise capital to pay off the Bank and regain control of MGM. The court rightly gave short shrift to this argument. The Bank retained veto rights over significant asset sales in any event ${ }^{74}-a$ standard term in every credit agreement, and one that gets tightened as a matter of routine in workout. Moreover, even absent a Bank veto, Parretti could hardly have expected that Ladd or the management structure created at the Bank's behest would do his bidding or fail to consider the Bank's wishes and interests, especially given the Bank's grip on the controlling shares of MGM. Parretti had relinquished control over MGM. He had also

to Parretti was appointed as President of MGM in an effort to repair the situation. Id. at 1129.

${ }^{72}$ In particular, Parretti negotiated for a provision that he needed only the votes of his own designees on the board of directors to cause the corporation to issue securities if the proceeds were used to retire the bank's debt. In effect, Parretti could buy out the bank's debt if he could find equity investors. Id. at 1119. "This point was significant. It meant that, if Parretti could find equity investors, he could use their investment to pay down debt and remove the bank from the picture, without having to involve the bank-designated directors or the executive committee comprised of the same individuals.” Id.

${ }^{73} \mathrm{Id}$. at 1122 n. 25 .

${ }^{74} \mathrm{Id}$. at 1154 . 
relinquished any expectation that MGM would be run for his benefit or the benefit of other pre-default shareholders.

Here, the actual terms of the arrangement between the Bank and MGM supply sufficient basis for concluding that Ladd's primary duty was to the creditors. None of the parties could have had any expectation otherwise. Their contract left no gaps to fill. ${ }^{75}$ The actual bargain obviated any need to construct a hypothetical bargain. While the famous vicinity-of-insolvency discussion was novel and interesting, its usefulness in deciding the case was limited. ${ }^{76}$

\section{B. The Actual Bargain in Production Resources}

Like Credit Lyonnais, the defaulted debt in Production Resources triggered a renegotiation between debtor and creditor. ${ }^{77}$ Pursuant to a "resolution agreement," the debtor agreed to register 6.7 million shares of its stock for the creditor's benefit. The debtor and its CEO apparently had also agreed at some point to sell stock owned by a subsidiary to pay off the debt. ${ }^{78}$ The debtor lived up to neither of these commitments, but instead made large payments to insiders and affiliated companies, according to the complaint.

The opinion offers no more detail on the terms of the renegotiated deal, but there may have been no more details to offer. The renegotiated deal was likely to have been much less elaborate than in Credit Lyonnais. The creditor Production Resources was a

75 Chancellor Allen's conclusion that the bank was acting in the interests of the entire community seems implausible, if only because the bank was acting antithetically to the expressed desires of one principal shareholder, obviously a member of the corporate community. Rather, consistent with the restructuring agreement, the bank was simply trying to get paid.

Lipson, supra note 9, at 1224.

76 See Amir N. Licht, The Maximands of Corporate Governance: A Theory of Values and Cognitive Style, 29 DEL. J. CORP. L. 649, 710 (2004) (noting that Chancellor Allen's discussion of vicinity-of-insolvency fiduciary duties was obiter dictum); Lipson, supra note 9, at 1224 \& n.162 (suggesting that Chancellor Allen's discussion of entity primacy "may be the worst kind of dicta-not simply irrelevant to the holding, but actually contrary to it.”).

77 Production Resources Group v. NCT Group, Inc., 863 A.2d 772, 778 (Del. Ch. 2004). 


\section{GAP FILLING IN THE ZONE OF INSOLVENCY}

trade creditor seeking to collect on "expensive computer controlled audio systems" supplied to the debtor. ${ }^{79}$ We might expect trade creditors' workouts with debtors to involve less elaborate agreements and less specific protections than when the creditor is a sophisticated financial institution. Trade creditors’ primary business, after all, is supplying goods or non-financial services. Collection, while no doubt important, is an ancillary activity, and trade creditors may generally not have the expertise to negotiate intricate financial covenants or other detailed protections that financial creditors enjoy.

Despite these relative disadvantages for the trade creditor, the gap filling rationale for IFDC fares no better in this context than with the sophisticated bank creditor in Credit Lyonnais. The post-default resolution agreement evidences that the parties negotiated specifically in anticipation of financial distress. Financial distress was not an overlooked contingency. Moreover, as with other cases, Production Resources presents a scenario suggesting strongly that existing debtor-creditor laws were sufficient to protect creditor interests. Fraudulent transfer and veil piercing come immediately to mind. "[T[he complaint does plead . . . that the board has engaged in conscious wrongdoing." 80

\section{DOES IFDC MATTER?}

If IFDC is unnecessary, is it harmful? The preceding discussion suggests that IFDC adds little to the extant legal and contractual protections creditors enjoy in the insolvency zone. This by itself would not imply that repeal of IFDC was necessary. The doctrine may simply be harmless, adding nothing but taking nothing away. Moreover, the literature on fiduciary duties to shareholders suggests that such duties may be fairly weak constraints on managerial misbehavior, especially the duty of care. Applying these duties in favor of creditors, therefore, may likewise not matter very much.

The potential for mischief may be small. However, as I describe below, a narrowing or repeal of the IFDC rule may still be warranted. At the margin, IFDC may enable creditors to impede efficient vicinity-of-insolvency investment. In addition, in a

\footnotetext{
78 Id at 801 n.88.

${ }^{79}$ Id. at 777.

$80 \mathrm{Id}$.
} 
world without IFDC, creditors have stronger incentives to craft explicit ex ante contractual restrictions to curb overinvestment. Explicit ex ante contract terms are likely to benefit shareholders as well as creditors, as compared to a regime in which creditor protection depends on a vague court-supplied ex post standard.

Below I first review the arguments for why the effects of IFDC are likely to be small. Next, I suggest that despite the small effects, an IFDC rule may do harm.

\section{A. IFDC May Not Matter}

1. Procedural Context: the Business Judgment Rule, Limitations on Liability, and Derivative Actions

The substantive content of fiduciary duties does not by itself describe the liability regime to which firm managers are subjected. The business judgment rule significantly ameliorates the possibility of liability by creating liberal running room for managers in the absence of fraud, illegality, or conflict of interest, 81 and provided that any decision making process was rational or conducted in good faith. ${ }^{82}$ In addition, "raincoat" statutes in Delaware and other states authorize corporations to insulate directors from money damages for breach of the duty of care through explicit charter provisions. ${ }^{83}$ Especially in public company charters, exculpation provisions are common. These insulating mechanisms should operate to shield managers from duty of care liability, whether the duty runs to shareholders or creditors. ${ }^{84}$ Therefore, including creditors as beneficiaries of the duty of care may matter little.

Similarly, IFDC claims are most likely to take the form of derivative actions. ${ }^{85}$ An IFDC rule therefore merely creates standing for creditors to press management to right

\footnotetext{
81 Shlensky v. Wrigley, 237 N.E. 2d 776 (Ill. App. 1968).

82 In re Caremark International Inc. Derivative Litigation, 698 A.2d 959 (Del. Ch. 1996).

83 E.g., Del. Gen. CorP. L. § 102(b)(7); Model Bus. CorP. ACT § 2.02(b)(4).

84 Production Resources so held. Production Resources Group v. NCT Group, Inc., 863 A.2d 772, 793 (Del. Ch. 2004).

85 Production Resources does leave open the possibility that a creditor may pursue a direct claim for self-dealing or bad faith. Id. at 799-800.
} 
wrongs done to the corporation. ${ }^{86}$ Whether managers are feathering their own nests or are merely incompetent, IFDC simply allows creditors to press the claims of the corporation in a representative capacity, as shareholders ordinarily do when the firm is solvent. ${ }^{87}$ Recoveries go to the firm, so the only question is which faction enjoys the right to press the claim. In this context of righting wrongs done to the firm, the interests of shareholders and creditors are likely to coincide in many cases. ${ }^{88}$ Even in the event of conflict, though, the insulating mechanisms described above suggest that managers will enjoy broad discretion despite the dissatisfaction of either shareholders or creditors.

\section{2. $\quad$ Existing Creditor Protection Rules}

Even in the absence of IFDC, legal rules exist to protect creditors from debtors' endgame maneuvers. Self-dealing while the firm is insolvent, for example, would typically trigger fraudulent transfer liability to creditors. ${ }^{89}$ Fraud, fraudulent transfer law, and veil piercing doctrine all seem to be implicated with some regularity in cases invoking IFDC rules. The cases in which IFDC rules may be critical are scarce.

\section{B. Repealing IFDC rules}

The incremental ex post benefit to creditors from IFDC rules appear to be very small. On the other hand, both ex post and ex ante effects of IFDC rules may possibly be pernicious. Ex post, as earlier noted, creditors may be able to block efficient investment by the firm when IFDC requires creditor wealth maximization..$^{90}$ Renegotiation to an efficient outcome may be difficult, since firm management might have to obtain the consent of multiple creditors. Leaving shareholders as the sole beneficiaries of management fiduciary

\footnotetext{
${ }^{86} \mathrm{Id}$. at 776.

${ }^{87}$ Id. at 792.

${ }^{88}$ For example, if managers are stealing from the corporation, all outside investors are harmed. The primary theoretical shareholder-creditor conflict involves overinvestment, but as we have discussed, there is some evidence that this conflict is more theoretical than real. See supra Part III.B.3.

89 The firm presumably does not receive reasonably equivalent value. Constructive fraud liability will therefore obtain. See Uniform FraUdUlent Transfer Act §§ 4(a)(2), 5(a). ${ }^{90}$ See supra Part III.B.2.
} 
duties is preferable, since efficient restrictions to prevent vicinity-of-insolvency overinvestment may be achieved by even one creditor.

Ex ante, both shareholders and creditors are likely to be better off with explicit contract terms, rather than vague ex post standards, to contain any overinvestment in the vicinity of insolvency. Vague standards may offer only episodic protection in any event, especially given the healthy insulation from duty of care liability that directors enjoy. To the extent the promise of vague court-implied future protection encourages creditors not to craft explicit zone-of-insolvency restrictions on firm management ex ante, all parties may be worse off. Vague standards invite both misbehavior and litigation. ${ }^{91}$

If it is costly for the courts to determine what the parties would have wanted, it may be efficient to choose a default rule that induces the parties to contract explicitly. In other words, penalty defaults are appropriate when it is cheaper for the parties to negotiate a term ex ante than for the courts to estimate ex post what the parties would have wanted. Courts, which are publicly subsidized, should give parties incentives to negotiate ex ante by penalizing them for inefficient gaps. ${ }^{92}$

\section{CONCLUSION}

The standard incomplete contracts approach to corporate fiduciary duties to shareholders does not translate neatly to justify fiduciary duties to creditors when a firm is at or near insolvency. Sophisticated commercial creditors have typically filled any gaps in their contracts by the time the firm approaches insolvency. Overinvestment seems a problem more theoretical than real, and in any event, crafting contractual curbs on overinvestment by shareholder-wealth-maximizing firm managers is likely to be easier than contracting around IFDC-induced inefficient investment restrictions. IFDC rules may

91 See Schwartz \& Scott, supra note 1, at 601-03 (noting that standards create moral hazard).

The vaguer the legal standard and the more that is at stake, the more likely the party is to resolve doubts in its own favor. A party that resolves doubts in this way will attempt to maximize private gains at the expense of joint welfare maximization. Therefore, a standard is efficient only when the party on whom it confers discretion has the incentive to maximize joint returns in the course of maximizing its private gain.

Id. at 603.

92 Ayres \& Gertner, supra note 56, at 93. 
not matter much, given the business judgment rule, raincoat statutes, the likelihood that many IFDC claims would be derivative, and the existence of other creditor protection rules. But vague standards should generally be avoided, and to the extent creditors do not already do so, they should be encouraged to draft their own vicinity-of-insolvency protections. 